\title{
ANTHROPOMETRIC STATUS AND NUTRITIONAL RISKS OF OLDER ADULTS IN UMUAHIA
} METROPOLIS, ABIA STATE NIGERIA

\author{
Nzeagwu O.C ${ }^{1}$, Iheme G.O. ${ }^{1}$ and Nkuku E.N. ${ }^{1}$ \\ ${ }^{1}$ Department of Human Nutrition and Dietetics, Michael Okpara University of Agriculture Umudike, Abia state, \\ Nigeria
}

Correspondence: ogechinzeagwu@gmail.com

\begin{abstract}
Background: A thorough nutritional assessment is necessary for successful diagnosis and development of appropriate/comprehensive treatment plans for malnutrition among older adults.

Objective: This study assessed the anthropometric status and nutritional risks of older persons in Umuahia Metropolis, Abia state.

Methods: The study was descriptive cross-sectional in design. A two-stage sampling technique was used to select 305 respondents. A structured questionnaire was used to elicit information on the relevant characteristics. Mini Nutritional Assessment (MNA) form and Malnutrition Universal Screening Tool (MUST) were used to categorize the respondents' nutritional risk. Anthropometric values were compared with their standard recommendations. Descriptive statistics were computed for the categorical and continuous variables using SPSS version 25

Results: The study findings revealed that a good number (44.3\%) of the older persons in the study area were between 60-64years, had family size of 4-6 members and earned income between $\$ 30,000-50,000$ (50.8\%) and above $\$ 50,000$ (45.9\%). Majority of the respondents were normal or at low risk of nutrition using MNA (89.2\%) and MUST (93.4\%) classification. Similarly, most of the older adults had normal body mass index (74.4\%), mid upper arm circumference (88.9\%), waist hip ratio $(65.2 \%)$ and calf circumference $(85.6 \%)$ status.

Conclusion: This study revealed that the respondents had normal/safe nutritional and health status using the various anthropometry and malnutrition assessment scales. Therefore, efforts to maintain healthy nutritional status and improve the socio-economic profile of older adults should be encouraged.
\end{abstract}

Keywords: Older adults, anthropometry, nutritional risk, Umuahia Nigeria

\section{INTRODUCTION}

Worldwide, the elderly population is increasing, and with it, the prevalence of malnutrition (1).

The global number of older persons is projected to rise from an estimated 524 million in 2010 to nearly 1.5 billion in 2050, with most of this increase in developing countries (1). Despite the significant medical advances, under-nutrition remains a significant and highly prevalent public health problem amongst older adults. This is a result of a gradual decline in general body function, decreased mobility and increasing level of dependency for livelihood associated with aging.

Estimates of the prevalence vary, as detection methods in older adults are not standardized. However, the prevalence of malnutrition is undeniably high: the overall prevalence is $22.6 \%$ (2). Nearly $40 \%$ of hospitalized older persons and 50\% of those in rehabilitation facilities are malnourished, and $86 \%$ are either malnourished or at risk of malnutrition (2). Up to $67 \%$ of older persons in nursing homes are malnourished or at risk of malnutrition while $38 \%$ of the older persons living in the community were at risk of malnutrition $38 \%$ (2).
Malnutrition may delay recovery and prolong hospitalization, leading to increased susceptibility to infection, impede individual's dependence and quality of life, and even increases the risk of death in many patients (3). Malnutrition poses a huge economic cost to society. The malnourished older persons are more likely to require health and social services, have more hospitalizations, and cause a burden on caregivers (4). Several studies (5-12) have reported the nutritional status of older adults in Nigeria using various reference standards, there is limited evidence on the nutrition risk level of older adults in South East Nigeria (9-12). Therefore, this study is designed to assess the anthropometric status and nutritional risk among older adults ( $\geq 60$ years) in Umuahia Metropolis.

\section{METHODS}

Study design

A cross sectional study design was employed in this study

\section{Study Area}

Umuahia is located along the rail road that lies between Port Harcourt to its South and Enugu city to its North. Umuahia has a population of 359,230 
DOI: $\underline{\text { https://dx.doi.org/10.4314/jdan.v12i1.4 }}$

according to the 2006 Nigerian census (13). Umuahia Metropolis is made up of Umuahia North and Umuahia South Local Government Areas. The agroecological climatic condition of the study area is typical of the tropics. Farming, trading and civil/public service jobs are the predominant occupations of the people of Umuahia.

\section{Sampling/sampling techniques}

The sample size was selected using a multi-stage sampling procedure. The five major clans in Umuahia metropolis were purposively selected. Simple random sampling procedure (balloting without replacement) was used to select five urban communities from each of the selected clans. Furthermore, the respondents were randomly selected. The five major clans and the selected communities in Umuahia metropolis include; Ahiaukwu Umuagwa community in Olokoro, Eziama Ussa in Umuokpara, Obuohia community in Ibeku, Apumeri in Ubakala and Isinkwo Amato community Ohuhu.

A sample size of 61 respondents was estimated using the statistical formula for calculating sample size of infinite population (6), $n=\frac{\mathrm{z}^{2} \mathrm{pq}}{\mathrm{d}^{2}}$

where $\mathrm{n}=$ sample size

$\mathrm{z}=$ Confidence interval of 1.96 or approximately 2

(constant)

$\mathrm{d}=$ tolerance/error

$\mathrm{p}=$ prevalence of older adults in Nigeria $-4 \%$

$(4,5)$

$\mathrm{p}=1-\mathrm{p}$

$\mathrm{n}=\frac{1.96^{2}(0.04)(0.96)}{0.05^{2}} \cong \quad 61$ respondents

Therefore, sample size was multiplied by the selected five (5) clans; $61 \times 5=305$ respondents

\section{Informed consent}

No adverse reactions were expected as the participants were interviewed and measured and no invasive procedures were carried out. Written consent was obtained from the respondents and only those who gave their informed consent were used for the study.

\section{Data collection}

Five (5) research assistants were selected and trained on the use of survey instruments.

Data was collected with an interviewer administered structured questionnaire. This was used to elicit information on the respondents' socio-economic characteristics, dietary habits and nutritional risks.

\section{Anthropometric Measurements}

Weight and height were assessed using standard procedures. The weight was measured using a bathroom scale, to the nearest $0.1 \mathrm{~kg}$ with the respondent barefooted and with minimum cloth on.

The heights of the respondents were measured using a stadiometer with the respondents standing erect on a flat platform with shoes removed looking straight ahead and hands in both sides. The movable head plate was then lowered into the crown of the head and read off to the nearest $0.1 \mathrm{~cm}$.

Body mass index (BMI) was calculated using weight in kilogram divided by the square of the height in metre. The BMI was classified using the WHO classification of BMI (14).

The respondents' waist and hip circumferences were measured using a non-stretchable tape. They were made to stand comfortably with their weight evenly distributed on both feet and the feet about 25 to $30 \mathrm{~cm}$ apart. The waist measurement was taken midway between the upper hip bone and the uppermost border of the right iliac crest. The tape was placed around the abdomen at the level of the midway point. Hip circumference on the other hand was measured with the respondents standing erect with arms at the sides and feet together. The researcher sat at side of the respondent so that the level of maximum extension of the buttocks was seen. The tape was placed around the buttocks in a horizontal plane. Readings were taken when the tape is snug but does not compress the skin and underlying soft tissues. The circumference was measured to the nearest $0.1 \mathrm{~cm}$ at the end of normal expiration (15).

The calf measurement was measured using a measuring tape. The measurement was on the right side of the leg. The respondents stood erect with their weight evenly distributed on both feet and legs slightly apart. The measuring tape was positioned horizontally around the largest circumference of the calf and measurement was taken to the nearest $0.1 \mathrm{~cm}$ (15).

MUAC circumference was measured using a measuring tape. The subject left hand was bent to the elbow at a 90-degree angle, with the upper arm held parallel to the side of the body. The tape were placed at the midpoint between the top of the shoulder and the tip of the elbow (olecranon process and the acronium) and measurement was taken to the nearest $0.1 \mathrm{~cm}$.

The values obtained from these circumference measures were computed and compared with standard categories $(16,17)$.

\section{Nutrition risk screening/assessment tools}

The Malnutrition Universal Screening Tool (MUST), for the ambulatory setting and the Mini Nutritional 
DOI: $\underline{\text { https://dx.doi.org/10.4314/jdan.v12i1.4 }}$

Assessment (MNA), for institutionalized generic patients $(18,19)$, were issued to the respondents and properly monitored to ensure it was properly filled and those who could not write well, were assisted by the researcher and the researcher assistant.

Scores were assigned to respondents' response to MNA questions on chewing/swallowing difficulties, mobility, weight loss, neuropsychological problems, Body Mass Index etc. and overall nutritional risk computed using the following categorization - 12-14 points: normal nutritional status; 8-11 points: at risk of malnutrition; 0-7 points: malnourished (18).

MUST examined three independent criteria; weight, unintentional weight loss and presence of acute disease. Each parameter was scored as 0, 1 and 2 . Patients are classified as low-risk (0), medium-risk (1) and high risk (>2) (19).

\section{Statistical analysis}

Data collected were entered into the computer and analyzed using the Statistical Package for Social Sciences (SPSS) version 25. Descriptive statistics were computed for the continuous and categorical variables.

\section{RESULTS}

Table 1 presents the result of the respondents' socioeconomic characteristics. A good number of the respondents were aged 60-64 (44.3\%) and 65-69 $(36.1 \%)$ years. More than half of them were females $(59.0 \%)$ while $41.0 \%$ were males. There were more married $(62.3 \%)$ than widowed $(30.8 \%)$ and divorced $(4.9 \%)$ persons. Christianity $(93.4 \%)$ and Igbo tribe (91.5\%) dominated the religious and ethnic groups respectively. The respondents reported having 1-3 $(22.6 \%)$ and 4-6 (59.0\%) household members. More than a quarter $(29.2 \%)$ and close to half $(45.9 \%)$ of the respondents had primary and secondary education, respectively. Less than half $(44.3 \%)$ and a quarter $(22.9 \%)$ of them were pensioners and farmers. Half $(50.8 \%)$ of the elderly received/earned income or allowance of $\$ 30,000-50,000$

Results from Table 2 revealed the anthropometric status of older adults. Results revealed that majority $(74.4 \%, 88.9 \% ; 85.6 \%)$ of them had normal body mass index, mid upper arm and calf circumference status, respectively. Results on waist circumference revealed that increased risk of metabolic diseases was observed in $59.0 \%$ of the respondents; also, waist hip ratio reports revealed that a good number $(34.8 \%)$ of the older adults were at risk of metabolic disease.

Information on the nutritional risk assessment of the respondents using MNA screening tool is summarized in Table 3. Results revealed that majority $(72.1 \%)$ of them had no food intake decline, weight loss $(>1 \mathrm{~kg})$ over the last 3 months was observed in $16.4 \%$ of the respondents. Majority $(91.8 \%)$ of them were mobile, had not experienced psychological stress/acute disease nor neuropsychological problems. Body Mass Index of $21-23 \mathrm{~kg} / \mathrm{m}^{2}(49.2 \%)$ and above $(49.2 \%)$ were observed in about half of the respective respondents. Results on the overall nutrition risk of older adults revealed that majority $(89.2 \%)$ of them had normal MNA status, $8.2 \%$ were at risk of malnutrition and $2.6 \%$ were classified malnourished.

Results from malnutrition universal screening tool (MUST) is summarized in Table 4. Results revealed that most $(68.2 \%)$ of them had a BMI value of 18.5$20-24.9 \mathrm{~kg} / \mathrm{m}^{2}$. More than half $(52.5 \%)$ of them were classified as low risk owing to their less than $5 \%$ weight loss in 3-6 months. Majority (75.4\%) of the respondents were at medium risk of acute disease. Low risk of malnutrition was observed in majority $(93.4 \%)$ of the respondents. 
Journal of Dietitians Association of Nigeria (JDAN) Volume 12. December, 2021 Print ISSN: 2141-8209; eISSN: 2635-3326

Available online at: $w$ ww.jdan.org.ng; https://www.ajol.info/index.php/jdan/index

DOI: https://dx.doi.org/10.4314/jdan.v12i1.4

Table 1: Socio-economic characteristics of the older persons

\begin{tabular}{|c|c|c|}
\hline Variables & Frequency $(\mathrm{N}=305)$ & Percentage (\%) \\
\hline \multicolumn{3}{|l|}{ Age (years) } \\
\hline $60-64$ & 135 & 44.3 \\
\hline $65-69$ & 110 & 36.1 \\
\hline $70-74$ & 30 & 9.8 \\
\hline $75-79$ & 20 & 6.5 \\
\hline 80 and above & 10 & 3.3 \\
\hline \multicolumn{3}{|l|}{ Sex } \\
\hline Male & 125 & 41.0 \\
\hline Female & 180 & 59.0 \\
\hline \multicolumn{3}{|l|}{ Marital status } \\
\hline Married & 190 & 62.3 \\
\hline Widowed & 94 & 30.8 \\
\hline Divorced & 15 & 4.9 \\
\hline Single & 6 & 2.0 \\
\hline \multicolumn{3}{|l|}{ Religion } \\
\hline Christianity & 285 & 93.5 \\
\hline Islamic & 5 & 1.6 \\
\hline Traditional & 15 & 4.9 \\
\hline \multicolumn{3}{|l|}{ Ethnic group } \\
\hline Igbo & 279 & 91.5 \\
\hline Hausa & 6 & 2.0 \\
\hline Yoruba & 8 & 2.6 \\
\hline Others & 12 & 3.9 \\
\hline \multicolumn{3}{|l|}{ Family size } \\
\hline $1-3$ & 69 & 22.6 \\
\hline $4-6$ & 180 & 59.0 \\
\hline $7-9$ & 45 & 14.8 \\
\hline Above 9 & 11 & 3.6 \\
\hline \multicolumn{3}{|c|}{ Highest Educational Qualification } \\
\hline No formal education & 10 & 3.3 \\
\hline Primary education & 89 & 29.2 \\
\hline Secondary education & 140 & 45.9 \\
\hline Tertiary education & 66 & 21.6 \\
\hline \multicolumn{3}{|l|}{ Occupation } \\
\hline Farming & 70 & 22.9 \\
\hline Trading & 30 & 9.8 \\
\hline Pensioner & 135 & 44.3 \\
\hline Artisan & 45 & 14.8 \\
\hline Others & 25 & 8.2 \\
\hline \multicolumn{3}{|c|}{ Monthly income/ allowance } \\
\hline$\approx 18,000-30,000$ & 10 & 3.3 \\
\hline$\$ 30,000-50,000$ & 155 & 50.8 \\
\hline Above $\$ 50,000$ & 140 & 45.9 \\
\hline
\end{tabular}


Table 2: Anthropometric status of the Older Persons

\begin{tabular}{lll}
\hline Variables & Frequency $(\mathbf{N}=\mathbf{3 0 5})$ & Percentage \\
\hline Body Mass Index & & \\
Underweight $\left(<18.5 \mathrm{~kg} / \mathrm{m}^{2}\right)$ & 11 & 3.6 \\
Normal $\left(18.5-24.9 \mathrm{~kg} / \mathrm{m}^{2}\right)$ & 227 & 74.4 \\
Overweight $\left(25.0-29.9 \mathrm{~kg} / \mathrm{m}^{2}\right)$ & 48 & 15.8 \\
Obese $\left(\geq 30.0 \mathrm{~kg} / \mathrm{m}^{2}\right)$ & 19 & 6.2 \\
Waist circumference & & \\
At risk (male $90-101 \mathrm{~cm} ;$ female:81-87cm) & 125 & 41.0 \\
Increased in risk (male102cm; female:88cm) & 180 & 59.0 \\
Waist hip ratio & & \\
Low risk/safe & 199 & 65.2 \\
(male: $\leq 0.09 \mathrm{~cm}$, female: $\leq 0.07)$ & & 34.8 \\
At-risk (male: $>1.0$, female: $>0.80)$ & 106 & 11.1 \\
Mid Upper Arm Circumference (MUAC) & & 88.9 \\
Malnourished (male:<23cm, female: $:<22 \mathrm{~cm})$ & 34 & \\
Normal (male: $24-30 \mathrm{~cm}$, female:23-30cm) & 271 & 85.6 \\
Calf circumference & & 14.4 \\
Normal $(\geq 31 \mathrm{~cm})$ & 261 & \\
At risk $(<31 \mathrm{~cm})$ & 44 & \\
\hline
\end{tabular}

Table 3: Nutritional risk of older adults using MNA

\begin{tabular}{|c|c|c|}
\hline Variables & Frequency $(\mathrm{N}=305)$ & Percentage \\
\hline \multicolumn{3}{|l|}{ Decline of food intake over the past 3 months } \\
\hline $0=$ severe decrease in food intake & 23 & 7.6 \\
\hline $1=$ moderate decrease in food intake & 62 & 20.3 \\
\hline $2=$ no decrease in food intake & 220 & 72.1 \\
\hline \multicolumn{3}{|l|}{ Weight loss during the last 3 months } \\
\hline $0=$ weight loss greater than $3 \mathrm{~kg}(6.6 \mathrm{lbs})$ & 25 & 8.2 \\
\hline $1=$ does not know & 163 & 53.4 \\
\hline $2=$ weight loss between 1 and $3 \mathrm{~kg}$ ( 2.2 and $6.6 \mathrm{lbs})$ & 25 & 8.2 \\
\hline $3=$ no weight loss & 92 & 30.2 \\
\hline \multicolumn{3}{|l|}{ Mobility } \\
\hline $0=$ bed or chair bound & 0 & 0.0 \\
\hline $1=$ able to get out of bed $/$ chair but does not go out & 25 & 8.2 \\
\hline $2=$ goes out & 280 & 91.8 \\
\hline \multicolumn{3}{|c|}{$\begin{array}{l}\text { Suffered psychological stress or acute disease in the past } 3 \\
\text { months }\end{array}$} \\
\hline $1=$ yes & 25 & 8.2 \\
\hline $2=$ no & 280 & 91.8 \\
\hline \multicolumn{3}{|l|}{ Neuropsychological problems } \\
\hline $0=$ severe dementia or depression & 5 & 1.6 \\
\hline $1=$ mild dementia & 20 & 6.6 \\
\hline $2=$ no psychological problems & 280 & 91.8 \\
\hline \multicolumn{3}{|l|}{ Body Mass Index (BMI) (kg/m²) } \\
\hline $0=$ BMI less than $19 \mathrm{~kg} / \mathrm{m}^{2}$ & 9 & 3.0 \\
\hline $1=$ BMI 19 to less than $21 \mathrm{~kg} / \mathrm{m}^{2}$ & 35 & 11.5 \\
\hline $2=$ BMI 21 to less than $23 \mathrm{~kg} / \mathrm{m}^{2}$ & 150 & 49.2 \\
\hline $3=\mathrm{BMI} 23$ or greater $\mathrm{kg} / \mathrm{m}^{2}$ & 111 & 36.4 \\
\hline \multicolumn{3}{|l|}{ Categorized Nutritional Risk } \\
\hline Normal (12-14) & 272 & 89.2 \\
\hline At risk $(8-11)$ & 25 & 8.2 \\
\hline Malnourished (0-7) & 8 & 2.6 \\
\hline
\end{tabular}


Journal of Dietitians Association of Nigeria (JDAN) Volume 12. December, 2021 Print ISSN: 2141-8209; eISSN: 2635-3326

Available online at: www.jdan.org.ng; https://www.ajol.info/index.php/jdan/index

DOI: https://dx.doi.org/10.4314/jdan.v12i1.4

Table 4: Nutritional risk factors of older adults using MUST

\begin{tabular}{lll}
\hline Variables & Frequency $(\mathbf{N}=\mathbf{3 0 5})$ & Percentage (\%) \\
\hline BMI Score & 11 & 3.6 \\
BMI $\left(<18.5 \mathrm{~kg} / \mathrm{m}^{2}\right)$ & 227 & 74.4 \\
BMI $\left(18.5-20-24.9 \mathrm{~kg} / \mathrm{m}^{2}\right)$ & 67 & 22.0 \\
BMI $\left(>25.0 \mathrm{~kg} / \mathrm{m}^{2}\right)$ & & \\
Weight loss in 3-6 months & 160 & 52.5 \\
Low-risk $(<5 \%)$ & 44 & 14.4 \\
Medium-risk $(5-10 \%)$ & 25 & 8.2 \\
High risk $(>10 \%)$ & 76 & 24.9 \\
Do not know & & \\
Acute disease effect & 45 & 14.8 \\
Low-risk & 230 & 75.4 \\
Medium-risk & 30 & 9.8 \\
High risk & & \\
Categorized Nutritional Risk & 285 & 93.4 \\
Low malnutrition risk $(0)$ & 15 & 5.0 \\
Medium malnutrition risk $(1)$ & 5 & 1.6 \\
High malnutrition risk $(>2)$ & & \\
\hline
\end{tabular}

\section{DISCUSSION}

In the present study, the anthropometric status and nutritional risk of older persons in Umuahia metropolis in Abia State, Nigeria was assessed. For the age of the older persons, $44.3 \%$ were between the ranged of 60 to 64 years, followed by 65-69 years with $36.1 \%$. This agrees with reports from Afolabi et al. (6) who reported that more than half of the elderly in their study were 58-68 years. The preponderance of under70 older adults may be partly due to poor survival capacities among the elderly population entrenched in the extent of poverty in the country (20).

Similarly, the preponderance of female (59.0\%) respondents observed in this study have been reported elsewhere (21). Christianity was the predominant religion in the area, this may be attributed to the location of the study.

The level of secondary education reported in this study compares closely with the findings of another study (6) which revealed reported that $48 \%$ respondents had attained secondary education. Several studies (22-24) affirmed that the educational level of the elderly significantly affect their health and nutritional status. The highest range of monthly income or allowance of the older persons fell between \#30,000 - \#50, 000 $(50.8 \%)$ while a good number of older persons earned below \#30000. This is not surprising because in Africa, particularly Nigeria, many older people retire at age 60 years and are left with insufficient personal savings, decreased earning capacity and increased reliance on pension and children/relatives' allowance to cater for their livelihoods (25).
The prevalence of overweight and obesity (21.9\%) reported in this study compares with findings from other studies $(26,27)$, where $23.9-30.0 \%$ of them reportedly had high body mass index $\left(\geq 25 \mathrm{~kg} / \mathrm{m}^{2}\right)$.

The high-risk level of a good number of the respondents in this study corroborates with findings of studies conducted in Abia State Nigeria (27) where high fat distribution was observed. Waist circumference and waist hip ratio are better predictors of abdominal fat or adiposity than other measures (28). Using the MNA tool, a high prevalence of normal nutrition among the sampled elderly population in Umuahia was found. It was observed that $2.6 \%$ of the participants were malnourished and $8.2 \%$ at risk of malnutrition. A technical brief published in 2012 reported similar findings among the elderly in the Pharping district of Nepal: $10 \%$ of the elderly were malnourished and $1 \%$ were at risk of malnutrition (29). However, other studies conducted in the South East (21) and South Western (30) Nigeria region reported that more than half and quarter of their subjects were at risk of malnutrition and malnourished, respectively. This indicates a low burden of malnutrition among the older persons in Umuahia Metropolis. Adequate nutrition promotes good nutritional status and thus satisfies the requirement for good physical health hence the risk of malnutrition is increased with unhealthy dietary habits and practices $(31,32)$.

Using the MUST tool, it was recorded that majority (93.4\%) of older persons had low nutritional risk. This agrees with other studies $(33,34)$ which reported a low MUST score $(\mathrm{k}=0.16-0.27)$ which indicates low nutritional risk. 


\section{CONCLUSION}

The study revealed that most of the respondents were considered to have normal/safe nutritional and health status using the various anthropometric and malnutrition assessment scales. Therefore, efforts to maintain healthy nutritional status and improve the living conditions of older adults should be encouraged.

Acknowledgement: The authors wish to thank the lecturers of the Department of Human Nutrition and Dietetics, Michael Okpara Univeristy of Agriculture, Umudike for their contribution to the success of this work

Ethics of human subject participation: This study was conducted according to the guidelines laid down in the Declaration of Helsinki. Written consent was obtained from the respondents after the study scope and objectives were communicated to them.

Funding: None

Conflict of interest: The authors have no conflict of interest to disclose

Author Contribution: Nzeagwu O.C. and Iheme G.O. formulated the research concept and design. Nkuku E.N. fully participated in the data collection. Iheme G.O and Nkuku E.N. compiled and analyzed the data. The manuscript was developed by Iheme G.O. and Nkuku E.N while Nzeagwu O.C. critically reviewed the manuscript. The final version submitted for publication was read and approved by all authors

Data and material availability: Data and materials used for this research are available from the author, upon reasonable request.

\section{REFERENCES}

1. Global Health and Aging. National Institute on Aging, National Institute of Health, United States: NIH Publication; 2011

2. Food Standards Agency (FSA). FSA nutrient and food-based guidelines for UK institutions; 2007. Available at http://www.food.gov.uk/sites/default/files/multi media/pdfs/nutrientinstitution.pdf

3. Wadas-Enright M, King A. Early recognition of malnutrition in the older adult: A quality improvement project using a standardised nutritional tool. J Community Health Nurs. 2015; 32:1-11.

4. Stratton RJ, Hackston A, Longmore D. Malnutrition in hospital outpatients and inpatients: prevalence, concurrent validity and ease of use of the 'Malnutrition Universal Screening Tool' ('MUST') for adults. Br J Nutr. 2004; 92:799-808.

5. Olasunbo OI and Olubode KA. Sociodemographic and nutritional assessment of the elderly Yorubas in Nigeria. IOSR J Nurs
Health Sc (IOSR- JNHS); Asian Pac J Clin Nutr. 2006;15 (1):95-100

6. Afolabi WAO, Olayiwola IO, Sanni SA, Oyawoye O. Nutrient intake and nutritional status of the aged in low income areas of South West Nigeria. J Aging Res Clin Practice. 2015; 4(1):65-72

7. Adebusoye LA, Ajayi IO, Dairo MD, Ogunniyi AO. Nutritional status of older persons presenting in a primary care clinic in Nigeria. $\mathbf{J}$ Nutr Gerontol Geriatr. 2012; 31(1):71-85.

8. Sanya EO, Kolo PM, Adekeye A, Ameh OI, Olanrewaju TO. Nutritional status of elderly people managed in a Nigerian tertiary hospital. Ann Afr Med. 2013;12:140-141

9. Nzeagwu OC. Evaluation of Nutritional Status Using Anthropometry and Biochemical Indices of Community Dwelling Older Persons in Nigeria. Current Research in Nutrition and Food Sci. 2016; 4(Special Issue -Elderly)

10. Akujobi, IC and Agbaghara, OT. Nutrition Knowledge and Nutrition Status of Elderly Hypertensive Patients in Ehime Mbano Local Government Area Imo State. J Diet Assoc Niger. 2018; 9 (1): 1-10.

11. Andia A, Fourera S, Souleymane B, Mamane D, Adehossi E. Evaluation of Nutritional Status at Household in Elderly Assessed by Mini Nutritional Assessment (MNA) in West Africa Country, Niamey-Niger. Am J Gerontol Geriatr. 2019; 2 (1): 1018

12. Nzeagwu OC and Ozougwu, CB Nutritional and health status of older persons aged $\geq 60$ years in rural communities of Udi Local Government Area, Enugu State, Nigeria. J Diet Assoc Niger. 2019; (10): 40-51.

13. National Population Commission, (NPC). Nigerian population census report; 2006.

14. World Health Organization (WHO). Obesity; Preventing and managing the global epidemic, report of a WHO consultation on Obesity. 1997. WHO/NUT/NCD/98. Geneva, Switzerland. htps://apps.who.int/iris/handle/10665/63854

15. Lee RD and Nieman DC. Nutritional assessment. ( $3^{\text {rd }}$ edition). Mc Graw-Hill company. Newyork. 2003 Pp 164-167.

16. Alberti KG, Zimmet P, Shaw J. The metabolic syndrome - a new worldwide defnition," Lancet. 2005; 366 (9491): 1059-1062.

17. World Health Organization (WHO). Physical Status: The Use and Interpretation of Anthropometry (Technical Report Series No. 854). World Health Organization, Geneva, Switzerland; 1997. Pp 452.

18. Vellas BJ, Garry PJ, Guigoz Y, Nestlé Nutrition Services \& Nestlé Clinical \& Performance 
Nutrition Workshop. Mini nutritional assessment (MNA): Research and practice in the elderly. Basel: Karger. 1999.

19. Kondrup J, Allison SP, Elia M, Vellas B, Plauth M. ESPEN guidelines for nutrition screening. J Clin Nutr. 2013; 22(3): 9-18.

20. Gaskill D, Black LJ, Isenring EA, Hassall S, Sanders F, Bauer JD. (2008). Malnutrition, prevalence and nutrition Issues in residential aged care facilities. The Australas J Ageing 27:189-190.

21. Nzeagwu OC and Uwaegbute AC. Assessment of nutritional vulnerability of the elderly using mini nutritional assessment tool (MNA). Niger J Nutr Sci. 2010; 31(1): 40-47.

22. Poda GG, Hsu CY, Rau HH, Chao JC. Impact of socio-demographic factors, lifestyle and health status on nutritional status among the elderly in Taiwan. Nutr Res Pract. 2019; 13(3):222-229.

23. Keino F. Lifestyle, nutritional status, health and mortality in elderly people across Europe: a review of the longitudinal results of the SENECA study. J Gerontol; Series A. Biol Sci. 2004; 59(12): 1277-1284.

24. Kimokoti RW and Hamer DH. Nutrition, health, and aging in sub-Saharan. Afr J Nutr. 2008; 66:611-623.

25. Agbola J. Nutritional assessment of some elderly farmers in rural areas of Ogun state, Nigeria ASSET Series B. Asset Inter J. 2014; 6(1):78-87.

26. Oguizu AD, Okudu HO, Etukudo AY. Anthropometry and dietary intake of the elderly in Eket local government area of Akwa Ibom state, Nigeria. Niger. J Nutr Sci 2018; 39 (1)
27. Nzeagwu O.C and Michael O.E (2018). Anthropometric status and dietary habits of hospitalized older persons in two major hospitals in Abia State, Nigeria. Nigerian Journal of Nutritional Sciences 39 (2): 179-193

28. Leitzmann MF, Moore SC, Koster A. (2011). Waist circumference as compared with body-mass index in predicting mortality from specific causes. Pub Library Sci -One 2011; 6: e18582.

29. Mebude HO and Frongillo, E.A. Nutritional and health consequences are associated with food insecurity among U.S. elderly persons. J. Nutr. 2010; 131:1503-1509.

30. Okoye C., Ogunyemi A., Abosede O. Care practices and nutritional status of the elderly in old people's homes in Lagos State, Nigeria. Niger J. Nutr Sci. 40 (1):91-98

31. Morillas J, Garcia-Talavera N, Martin-Pozuelo G, Reina AB, Zafrilla P. [Detection of hyponutrition risk in non- institutionalised elderly]. Nutri Hosp. 2006; 21: 650-656.

32. Lyons E. Principles of Nutritional Assessment, 2nd ed, 1-45. New York: Oxford University Press. 2012.

33. Adamu D, Adebusoye LA, Ajayi IO, Dairo MD, Ogunniyi AO. Factors associated with under nutrition and overweight in Elderly patients presenting at a primaryhealth care Clinics in Nigeria. South Afr Farm Pract. 2012; 53(4):355360.

34. Baweja P, Fogaça KC, Leandro-Merhi, VA. Nutritional status and functional capacity of hospitalized elderly. Nutr J. 2008; 17(8):54-62 